\title{
Fully “Recombinant Enzyme-Linked Immunosorbent Assays" Using Genetically Engineered Single-Chain Antibody Fusion Proteins for Detection of Citrus tristeza virus
}

\author{
Estela Terrada, Randolf J. Kerschbaumer, Giuseppe Giunta, Patrizia Galeffi, \\ Gottfried Himmler, and Mariano Cambra
}

\begin{abstract}
First and sixth authors: Instituto Valenciano de Investigaciones Agrarias, Carretera Moncada-Naquera km 4.5, 46113 Moncada, Valencia, Spain; second author: Institute of Applied Microbiology, University of Agriculture and Forestry, Muthgasse 18, A1190 Vienna, Austria; third and fourth authors: ENEA CR Cassacia, Dep. Innovazione, Div. Biotecnologie e Agricoltura, Sec. Biofisica, Biochimica and Biologia Molecolare, via Anguillarese, 30100060 S. Maria di Galeria, Roma, Italy; and fifth author: CODON Genetic Systems GmbH, Vienna, Austria.
\end{abstract}

Accepted for publication 23 August 2000.

\begin{abstract}
Terrada, E., Kerschbaumer, R. J., Giunta, G., Galeffi, P., Himmler, G., and Cambra, M. 2000. Fully "recombinant enzyme-linked immunosorbent assays" using genetically engineered single-chain antibody fusion proteins for detection of Citrus tristeza virus. Phytopathology 90:1337-1344.

Recombinant single-chain variable fragment antibodies ( $\mathrm{scFv}$ ) that bind specifically to Citrus tristeza virus (CTV), which cause the most detrimental viral disease in the citrus industry worldwide, were obtained from the hybridoma cell lines 3DF1 and 3CA5. These scFv were geneti-

cally fused with dimerization domains as well as with alkaline phosphatase, respectively, and diagnostic reagents were produced by expressing these fusion proteins in bacterial cultures. The engineered antibodies were successfully used for CTV diagnosis in plants by tissue print enzymelinked immunosorbent assay (ELISA) and double antibody sandwichELISA. The fully recombinant ELISAs were as specific and sensitive as conventional ELISAs performed with the parental monoclonal antibodies, showing the usefulness of recombinant antibodies for routine detection of a virus in woody plants for the first time.
\end{abstract}

Tristeza is one of the most destructive diseases of citrus worldwide (4). It is caused by Citrus tristeza virus (CTV), which is naturally spread by aphids in a semipersistent manner and is also easily transmitted by grafting (3). Since 1957 the disease has caused the decline and death of close to 40 million trees grafted on sour orange rootstocks in Spain (12) and several million trees in other citrus growing areas in the Americas, Australia, and South Africa (4). CTV is a monopartite virus with flexuous-filamentous particles of approximately $11 \times 2,000 \mathrm{~nm}$ (3). It has a plus sense single-stranded RNA genome of approximately 19,296 nucleotides (25) encapsidated in the coat protein $(25 \mathrm{kDa})$. The virus has numerous isolates differing in biological (symptoms and aphid transmissibility) and serological properties $(1,8,9,39)$ and genome sequence $(25,46)$.

The control of this economically important virus is achieved by preventive methods such as quarantine, use of disease free budwood and CTV-tolerant rootstocks. Eradication programs and the use of cross-protection strategies with mild isolates can also contribute to the control of the disease (40). All these control strategies require a large number of detection tests usually performed by enzyme-linked immunosorbent assays (ELISA) with polyclonal or monoclonal antibodies (MCA) $(2,13,17)$. The best results are obtained by specific MCAs $(17,45)$ produced by hybridoma technology (29). In spite of the high serological variability of the virus, a mixture of two MCAs (3DF1 and 3CA5) are able to detect all CTV isolates tested (10). These antibodies, patented in 1984 (No. 536923RPI), are well characterized $(10,33,44,45)$ and

Corresponding author: M. Cambra; E-mail address: mcambra@ivia.es

Publication no. P-2000-1013-01R

(C) 2000 The American Phytopathological Society are considered an international reference for CTV diagnosis. In addition, the 3DF1 epitope has been identified (35). With these commercially available MCAs (INGENASA, Madrid, Spain), approximately 2 million samples have been analyzed since 1990 . For these reasons we selected both MCAs to be subcloned from hybridoma cell lines and expressed in Escherichia coli as singlechain variable fragment antibody ( $\mathrm{scFv}$ ) fusion proteins to be used in a number of ELISA variants for CTV detection.

The $\mathrm{scFv}$ technology $(5,23)$ allows the cloning of variable (V) genes from pre-existing MCA cell lines, linking them with a flexible peptide as a single chain $\mathrm{Fv}$ ( $\mathrm{scFv}$ ). These constructs can be expressed in bacteria $(19,36,37)$ as soluble proteins or fused with the capsid proteins of filamentous phages (47). In addition, antibody genes can be expressed fused with other proteins such as alkaline phosphatase (AP) $(15,28)$ or with amphipathic helices $(27,34,37)$. The expression of these antigen binding proteins in bacterial cultures provides standardized diagnostic reagents that are theoretically able to replace conventional monoclonal or polyclonal antibodies and conjugates, providing significant advantages in time and cost. However, their applications for diagnostic purposes are scarce. In plant pathology, serological detection is widely used, but although some recombinant constructs have been produced $(6,20,21,27,32,42,43,48)$ only few of them have been applied for routine ELISA tests.

The goal of this work was to produce engineered $\mathrm{scFv}$ fusion proteins for detection of CTV and to evaluate their ability to detect the virus under routine assay conditions in comparison with conventional MCAs. To our knowledge, this is the first report that homologous recombinant antibodies are as efficient and useful as conventional MCAs for routine detection of a virus in woody plant materials. The success of the developed engineered reagents in binding and detecting CTV in extracts and in tissue blots opens new possibilities for easy and fast production of detecting reagents. 


\section{MATERIALS AND METHODS}

VH and VL amplification. Purification of mRNA from 3CA5 and 3DF1 CTV-specific hybridoma cell lines (stored at INGENASA) was performed with a micro mRNA purification kit (Quick-Prep, Amersham Pharmacia Biotech, Uppsala, Sweden). The cDNA was obtained by reverse transcription of this mRNA with the specific primers $\mathrm{CH} 1 \mathrm{FOR}$ (an equimolar mixture of MOCG1-2FOR: 5' CTC AAT TTT CTT GTC CAC CTT GGT GC 3'; MOCG3FOR: 5' CTC GAT TCT CTT GAT CAA CTC AGT CT 3'; and MOCMFOR: 5' TGG AAT GGG CAC ATG CAG ATC TCT 3') and CKFOR (5' CTC ATT CCT GTT GAA GCT CTT GAC 3') (H. Hoogenboom, unpublished data). VH and VL regions of both antibodies were amplified by polymerase chain reaction with cDNAs as templates with primers VH1backSfi $\left(5^{\prime} \mathrm{C}\right.$ ATG CCA TGA CTC GCG GCC CAG CCG GCC ATG GCC SAG GTS MAR CTG CAG SAG TCW GG 3'), VH1for2LiAsc (5' ACC GCC AGA GGC GCG CCC ACC TGA ACC GCC TCC ACC TGA GGA GAC GGT GAC CGT GGT CCC TTG GCC CC 3'), Vk4forNot (an equimolar mixture of JK1NOT10: 5' GAG TCA TTC TGC GGC CGC CCG TTT GAT TTC CAG CTT GGT GCC 3'; JK2NOT10: 5' GAG TCA TTC TGC GGC CGC CCG TTT TAT TTC CAG CTT GGT CCC 3'; JK4NOT10: 5' GAG TCA TTC TGC GGC CGC CCG TTT TAT TTC CAA CTT TGT CCC 3'; and JK5NOT10: 5' GAG TCA TTC TGC GGC CGC CCG TTT CAG CTC CAG CTT GGT CCC 3'), and Vk2backLiAsc (5' GGT TCA GAT GGG CGC GCC TCT GGC GGT GGC GGA TCG GAC ATT GAG CTC ACC CAG TCT CCA $\left.3^{\prime}\right)$. These primers are based on the primers previously reported (14), which were modified to introduce the AscI site and the linker sequence (16). Alternatively $\mathrm{VH}$ and $\mathrm{VL}$ regions from MCA 3DF1 were amplified with primers VH1FOR2 (5' TGA GGA GAC GGT GAC CGT GGT CCC TTG GCC CCA 3'), VK1FOR (5' CCG TTT GAT CTC GAG CTT GGT GCC 3'), VK1BACK (5' GAC ATC GAG CTC ACT CAG TCT CCA 3'), and VH1BACK (5' AG GTS MAR CTG CAG SAG TCW GG 3') (14).

Cloning in pDAP2, pDAP2/S, pZIP, and pCLZIP vectors. Each VH sequence was amplified with VH1backSfi and Vh1forLiAsc and cloned into SfiI- and AscI-digested pDAP2 (28). Transformation of E. coli TG1, plasmid purification, and selection of recombinants were performed by standard protocols (41). The plasmid DNA of 10 clones harboring the respective $\mathrm{VH}$ region were pooled and restricted with $A s c \mathrm{I}$ and NotI. The corresponding VL sequence, amplified with Vk4forNot and Vk2backLiAsc, was inserted and E. coli TG1 were transformed with these constructs. Individual clones of the resultant pDAP2-3DF1scFv and pDAP2$3 \mathrm{CA} 5 \mathrm{scFv}$ constructs were expressed in a $20-\mathrm{ml}$ scale for screening as described (27), and the supernatants were checked for scFvAP fusions with binding activity by double-antibody sandwich (DAS)-ELISA (described below).

TABLE 1. Comparison of double-antibody sandwich, enzyme-linked immunosorbent assay (ELISA) optical density at $405 \mathrm{~nm}\left(\mathrm{OD}_{405}\right)$ values obtained with extracts of sweet orange cv. Pineapple noninfected and infected with Citrus tristeza virus (CTV) isolates T-388, T-397-P, and T-302a

\begin{tabular}{lcccc}
\hline & \multicolumn{4}{c}{$\mathrm{OD}_{405}{ }^{\mathrm{b}}$} \\
\cline { 2 - 5 } Isolate & 3DF1scFv-AP/S & 3DF1 & 3CA5scFv-AP/S & 3CA5 \\
\hline T-388 & $1.062 \pm 0.035$ & $0.892 \pm .0004$ & $0.792 \pm 0.018$ & $0.876 \pm 0.034$ \\
T-397-P & $0.053 \pm 0.005$ & $0.056 \pm 0.002$ & $0.501 \pm 0.027$ & $0.606 \pm 0.049$ \\
T-302 & $1.188 \pm 0.004$ & $1.031 \pm 0.004$ & $0.814 \pm 0.025$ & $0.901 \pm 0.007$ \\
Control & $0.043 \pm 0.001$ & $0.072 \pm 0.004$ & $0.072 \pm 0.005$ & $0.046 \pm 0.004$ \\
\hline
\end{tabular}

a The method was performed by coating microplates with a mixture of monoclonal antibodies (MCAs) 3DF1 and 3CA5 and with 3DF1scFv-AP/S or $3 \mathrm{CA} 5 \mathrm{scFv}-\mathrm{AP} / \mathrm{S}$ as recombinant conjugates or alkaline phosphataseconjugated MCAs 3DF1 or 3CA5. The isolate T-397-P, defective in the 3DF1 epitope (9), was not detected by 3DF1 MCA or 3DF1scFv but was detected by 3CA5 MCA and 3CA5scFv.

b Average of four ELISA wells containing $100 \mu$ per well after $1 \mathrm{~h}$ substrate incubation.
The $3 \mathrm{CA} 5 \mathrm{scFv}$ and $3 \mathrm{DF} 1 \mathrm{scFv}$ with $\mathrm{CTV}$ binding properties were subcloned from pDAP2 into SfiI/NotI-digested pDAP2/S and pZIP1 vectors (26). 3CA5scFv was also inserted in vector pCLZIP (26). Transformation of $E$. coli TG1 was done as described (41).

Cloning in pEMBL-ENEA and pHEN-ENEA vectors. The pEMBL-ENEA contains a scFv cassette HindIII/EcoRI consisting of the VH region (inserted into PstI and BstEII restriction sites), the linker sequence, the VL region (inserted into $\mathrm{SacI}$ and XhoI restriction sites), and finally the c-myc tag sequence. The $\mathrm{VH}$ cDNA derived from MCA 3DF1 was amplified with VH1FOR2 and VH1BACK and was PstI/BstEII-inserted into the plasmid. In a second cloning step, the VL-gene, amplified with VK1FOR and VK1BACK, was inserted between the SacI and XhoI restriction sites of pEMBL-ENEA containing the VH gene. After sequence analysis, the 3DF1scFv gene was excised from pEMBL-ENEA and was swapped into pHEN vector (22) for prokaryotic expression. The pHEN vector was used to transform E. coli HB2151.

Sequence. Both $\mathrm{scFv}$ fragments were sequenced with an aflatoxin biosynthesis inhibitor (PRISM DNA Sequencer 377, Perkin-Elmer, Langen, Germany) or by CEINGE Service, Naples University.

Expression, purification, and storage of the recombinant diagnostic reagents. The expression products of the pDAP2/S constructs (3DF1scFv-AP/S and 3CA5scFv-AP/S), of the pZIP1 constructs (3DF1scFv-ZIP and 3CA5scFv-ZIP), and of the pCLZIP construct (3CA5scFv-CLZIP) were obtained by incubating the respective E. coli TG1 clones at $16^{\circ} \mathrm{C}$ for $72 \mathrm{~h}$. Proteins (except $3 \mathrm{CA} 5 \mathrm{scFv}-\mathrm{AP} / \mathrm{S}$ ) were purified from cultured supernatant by immobilized metal affinity chromatography as described (27). The molecular weight of the purified proteins was verified by sodium dodecyl sulfate-polyacrylamide gel electrophoresis (SDS-PAGE). The $3 \mathrm{CA} 5 \mathrm{scFv}-\mathrm{AP} / \mathrm{S}$ fusion protein was concentrated from the supernatant by ammonium sulfate precipitation, redissolved in Luria-Bertani (LB) medium, and dialyzed against LB medium diluted 1:1 with phosphate-buffered saline (PBS). HB2151 bacteria containing the $\mathrm{pHEN}-3 \mathrm{DF} 1 \mathrm{scF}$ v plasmid were induced for expression by incubating them with isopropyl- $\beta$-D-thiogalactopyranoside $(1 \mathrm{mM})$ at $25^{\circ} \mathrm{C}$ for $16 \mathrm{~h}$. Several periplasmic extraction methods were tested: (i) protein borate extraction, after induction, bacterial pellet was resuspended in 1:10 volume of $200 \mathrm{mM}$ sodium borate buffer ( $\mathrm{pH} 8.0$ ) containing $160 \mathrm{mM} \mathrm{NaCl}$, incubated on ice for $1 \mathrm{~h}$, and centrifuged $15 \mathrm{~min}$ at $12,000 \times \mathrm{g}$; (ii) protein mild extraction: bacterial pellet was treated with a mild osmotic shock in 0.2 M Tris- $\mathrm{HCl}$ ( $\mathrm{pH} 8.0), 0.5 \mathrm{mM}$ EDTA, and $0.5 \mathrm{M}$ Sucrose, diluted in water $1: 4$, incubated at $0^{\circ} \mathrm{C}$ for $30 \mathrm{~min}$, centrifuged at $5,000 \times g$ for $10 \mathrm{~min}$, and centrifuged again at $48,000 \times g$ for $15 \mathrm{~min}$; and (iii) protein urea extraction (38). In each case, protein extracts were collected in the final supernatant and analyzed by SDS-PAGE and western blot. The membranes were incubated with MCA antitag 9E10 for detection of scFv. NaAzide $(0.1 \%)$ was added to the purified proteins and to concentrated $3 \mathrm{CA} 5 \mathrm{scFv}-\mathrm{AP} / \mathrm{S}$ and stored in aliquots at $4{ }^{\circ} \mathrm{C}$ or at $-20^{\circ} \mathrm{C}$, mixed with an equal volume of glycerol.

Tissue print ELISA. Immunoprinting or direct tissue print immunoassay (30) was performed as described for CTV detection $(7,11,18)$. Nitrocellulose membranes (HA45, Millipore Corp., Bedford, MA) were used to imprint fresh sections of healthy and CTV-infected plant materials. The following species were used as healthy controls: sweet orange (Citrus aurantifolia) cvs. Pineapple and Mexican lime (C. aurantium). The infected plant material had been previously inoculated with a number of CTV isolates from the collection maintained at Instituto Valenciano de Investigaciones Agrarias (IVIA). The selected isolates differed in aggressiveness: T-388 (very aggressive), T-397 and T-397-P (intermediate), and T-302 (mild). The isolate T-397-P, defective in 3DF1 epitope (9), was not recognized by 3DF1 MCA. The printed membranes were blocked by incubation in $1 \%$ bovine serum albumin in distilled water for $1 \mathrm{~h}$. Tissue print direct ELISA was performed by 
incubation of the membranes for $3 \mathrm{~h}$ at room temperature, in parallel assays, with $3 \mathrm{CA} 5 \mathrm{scFv}-\mathrm{AP} / \mathrm{S}, 3 \mathrm{DF} 1 \mathrm{scFv}-\mathrm{AP} / \mathrm{S}$, or with the calf intestinal AP-labeled parent MCA. Tissue print indirect ELISA was also carried out by incubating the printed membranes with $3 \mathrm{DF} 1 \mathrm{scFv}$ for $2 \mathrm{~h}$. After washing, membranes were sequentially incubated with MCA 9E10 and with AP-conjugated goat anti-mouse immunoglobulins (Sigma Aldrich, Madrid). In both tissue print ELISAs, after washing, nitro blue tetrazolium and 5-bromo-4-chloro-3-indolyl phosphate (Sigma) were used as substrate. The processed membranes were washed in water, dried, and examined under a binocular microscope at 5 to $20 \times$ magnification.

DAS-ELISA. ELISA microplates (PolySorp, Nalge Nunc International, Rochester, NY) were coated by incubating for $4 \mathrm{~h}$ at $37^{\circ} \mathrm{C}$ with polyclonal immunoglobulins from antiserum CTV/MN2IVIA $(2 \mu \mathrm{g} / \mathrm{ml})$, specific monoclonal antibodies 3DF1 and 3CA5 $(1 \mu \mathrm{g} / \mathrm{ml})$, or recombinant fragments $3 \mathrm{DF} 1 \mathrm{scFv}-\mathrm{ZIP}, 3 \mathrm{CA} 5 \mathrm{scFv}-$ ZIP, or 3CA5scFv-CLZIP $(10 \mu \mathrm{g} / \mathrm{ml})$, each diluted in $0.1 \mathrm{~N}$ sodium carbonate buffer $(\mathrm{pH}$ 9.6). The plates were washed and incubated overnight at $4^{\circ} \mathrm{C}$ with extracts from infected citrus plants. Extracts were prepared by grinding the plant material previously inoculated with CTV isolates T-388, T-397-P, and T-302 (described previously) in PBS- $0.2 \%$ diethyldithiocarbamate or in a more complex buffer (PBS, $2 \%$ ovalbumin, $2 \%$ polyvinylpyrrolidone, $10 \mathrm{mM}$ EDTA, and $0.2 \%$ Tween 20 at $\mathrm{pH} 7.2$ ) at a ratio of 1:20 (wt/vol). For detection of the immobilized antigen, $3 \mathrm{DF} 1 \mathrm{scFv}-\mathrm{AP} / \mathrm{S}$ or $3 \mathrm{CA} 5 \mathrm{scFv}-\mathrm{AP} / \mathrm{S}$ (diluted in PBS) were added to the microplate wells and incubated for $3 \mathrm{~h}$ at $37^{\circ} \mathrm{C}$. As a positive control, AP-conjugated MCAs 3DF1 and 3CA5 $(0.1 \mu \mathrm{g} / \mathrm{ml})$ were used. After washing, the plates were incubated at room temperature with $1 \mu \mathrm{g} / \mathrm{ml}$ of $p$-nitrophenyl phosphate in substrate buffer (10\% diethanolamine in distilled water, $\mathrm{pH} 9.8)$. Optical density (OD) at $405 \mathrm{~nm}$ was measured in a photometer (MultisKan, Titertek, Huntsville, AL) zeroed with an empty plate, after 30, 60, 90, and $120 \mathrm{~min}$ of incubation.

For statistical analysis of the different DAS-ELISA formats performed, a one-way analysis of variance using ELISA format as factor was carried out for each isolate $\times$ antibody combination. A LSD test was used for mean comparison.

\section{RESULTS}

Synthesis of $\mathbf{s c F v}$ fragments able to react against CTV. Two different approaches were chosen to obtain functional $\mathrm{scFv}$ after subcloning from hybridoma cells. In our first strategy, the $\mathrm{VH}$ and VL regions of MCA 3DF1 were sequentially inserted into pEMBL-ENEA. The resulting scFv-cassette was subcloned into pHEN1 and was expressed as a fusion with the c-myc tag. Clones that expressed 3DF1scFv with CTV specificity were identified by a MCA 9E10-mediated ELISA. SDS and western blot analyses suggested that the urea extraction method had 1,000-fold better yield than the mild extraction method for recovering $3 \mathrm{DF} 1 \mathrm{scFv}$ protein. However, these conditions were not useful for recovering functional $\mathrm{scFv}$ and a subsequent refolding process had to be performed. Hence, the mild extraction method was used to prepare active 3DF1-scFv for use in tissue print ELISA.

Alternatively, the cDNA of $\mathrm{VH}$ and VL of MCA 3DF1 were amplified with primers VH1for2LiAsc and Vk2backLiAsc, respectively, each providing the coding sequence of half of the linker sequence. The VH and VL regions were sequentially cloned into pDAP2, thus joining the two linker halves via the AscI restriction site and also linking the $\mathrm{scFv}$ fusion to the coding region of $E$. coli wild-type AP (schematic representation of the scFv fusions obtained is shown in Figure 1). The presence of functional $\mathrm{scFv}$ gene sequences was confirmed by expression of several colonies, and examination of the scFv-AP fusion protein secreted into the supernatant for CTV binding activity by DAS-ELISA. The latter approach requires fewer cloning steps and also is easier for testing the scFv-AP fusion proteins. We therefore used this method for subcloning the $\mathrm{scFv}$ region from hybridoma cell line 3CA5. For each subcloned MCA, 3DF1 and 3CA5, several clones expressing a highly specific scFv-AP fusion protein were obtained.

The sequences of both $\mathrm{scFv}$ fragments, $3 \mathrm{DF} 1 \mathrm{scFv}$, and 3CA5scFv were determined (GenBank Accession No. AF162709 and AF162710, respectively), and compared with the sequences available in the Kabat (1987) database (24). A comparison with inferred amino acid sequences confirmed that the expected amino acids were present in the predicted positions.

Recombinant conjugates. $3 \mathrm{DF} 1 \mathrm{scFv}$ and $3 \mathrm{CA} 5 \mathrm{scFv}$ were subcloned into vector $\mathrm{pDAP} 2 / \mathrm{S}$ (27) to fuse the scFv to an improved E. coli alkaline phosphatase (AP/S). In this construct the ecphoA1 gene was mutated to give a fusion protein with a 35 -fold improved specific activity (31). After expression and purification of the $\mathrm{AP} / \mathrm{S}$-fused scFv proteins, their efficiency as detection reagents was determined by DAS-ELISA and compared with the efficiency of conventional MCAs. Purified 3DF1scFv-AP/S was able to detect different CTV isolates in infected plants with the same specificity and sensitivity as the parental antibody (Table 1). In contrast, 3CA5scFv-AP/S only identified CTV-infected plants prior to its purification; enzymatic and binding activity was lost after purification. The supernatant of $3 \mathrm{CA} 5 \mathrm{scFv}-\mathrm{AP} / \mathrm{S}$ was concentrated by ammonium sulfate precipitation, and the fusion protein stabilized by redissolving in LB medium and dialysis. This process yielded a recombinant conjugate that was nearly as specific and sensitive as the parental MCA 3CA5 (Table 1). The same results were obtained when both $\mathrm{scFv}-\mathrm{AP} / \mathrm{S}$ fusions were tested by tissue print direct ELISA for detection of CTV (described below). Both recombinant conjugates, purified $3 \mathrm{DF} 1 \mathrm{scFv}-\mathrm{AP} / \mathrm{S}$ and nonpurified, but concentrated, and $3 \mathrm{CA} 5 \mathrm{scFv}-\mathrm{AP} / \mathrm{S}$ were stable after storage at $4^{\circ} \mathrm{C}$ (after addition of $\mathrm{Na}$ Azide) or at $-20^{\circ} \mathrm{C}$ in $50 \%$ glycerol for 15 months (Table 2).

Coating reagents. $3 \mathrm{DF} 1 \mathrm{scFv}$ and $3 \mathrm{CA} 5 \mathrm{scFv}$ were subcloned from pDAP2 into the vector pZIP1 (27) allowing expression of $\mathrm{scFv}$ fragments dimerized by a leucine zipper domain (miniantibodies) (34; Fig. 1). Both scFv fusions (3DF1scFv-ZIP and $3 \mathrm{CA} 5 \mathrm{scFv}-\mathrm{ZIP}$ ) could be purified and immobilized on microplate wells and were able to trap CTV from a semipurified virus preparation. However, when the fused proteins were tested for trapping CTV coat protein (CP) in presence of plant material, reactivity of $3 \mathrm{CA} 5 \mathrm{scFv}-\mathrm{ZIP}$ was poor. This poor reaction was not observed for $3 \mathrm{DF} 1 \mathrm{scFv}-\mathrm{ZIP}$. To circumvent this problem with $3 \mathrm{CA} 5 \mathrm{scFv}-\mathrm{ZIP}$, the scFv3CA5 gene was subcloned into another vector, pCLZIP (26), and expressed as a mini-antibody enlarged by a CL-domain positioned between the $\mathrm{scFv}$ and the leucine zipper. This new fusion protein (3CA5scFv-CLZIP) was able to trap CTV antigens in the presence of plant material. The trapping of CTV after application of plant extracts on wells coated with 3DF1scFv-ZIP and

TABLE 2. Optical density at $405 \mathrm{~nm}\left(\mathrm{OD}_{405}\right)$ values of Citrus tristeza virus isolates obtained by enzyme-linked immunosorbent assays (ELISA) with single-chain variable antibody fragments $(\mathrm{scFv})$ fusion proteins freshly prepared, stored at $4^{\circ} \mathrm{C}$, and at $-20^{\circ} \mathrm{C}$ for 15 months

\begin{tabular}{lccccc}
\hline Coating reagent $^{\mathrm{a}}$ & Isolate & & Fresh & $4^{\circ} \mathrm{C}$ & $-20^{\circ} \mathrm{C}$ \\
\hline 3DF1scFv-AP/S & $\mathrm{T}-388$ & $1.824 \pm 0.087$ & $1.690 \pm 0.063$ & $1.784 \pm 0.073$ \\
& $\mathrm{~T}-302$ & $1.591 \pm 0.102$ & $1.643 \pm 0.074$ & $1.453 \pm 0.067$ \\
3CA5scFv-AP/S & $\mathrm{T}-388$ & $1.225 \pm 0.046$ & $1.065 \pm 0.089$ & $1.116 \pm 0.058$ \\
& $\mathrm{~T}-302$ & $0.998 \pm 0.035$ & $1.103 \pm 0.066$ & $0.932 \pm 0.074$ \\
3DF1scFv-ZIP & $\mathrm{T}-388$ & $1.430 \pm 0.044$ & $\mathrm{NA}$ & $1.706 \pm 0.021$ \\
& $\mathrm{~T}-302$ & $0.974 \pm 0.056$ & $\mathrm{NA}$ & $1.001 \pm 0.045$ \\
3 3CA5scFv-CLZIP & $\mathrm{T}-388$ & $0.985 \pm 0.032$ & $\mathrm{NA}$ & $0.914 \pm 0.033$ \\
& $\mathrm{~T}-302$ & $0.704 \pm 0.054$ & $\mathrm{NA}$ & $0.756 \pm 0.046$ \\
\hline
\end{tabular}

a ELISA performed by coating with a mixture of 3DF1 and 3CA5 monoclonal antibodies (MCAs) and using the different scFv-AP/S fusions separately as detecting antibodies or by coating with 3DF1scFv-ZIP or 3CA5scFv-CLZIP with a mixture of MCAs 3DF1 and 3CA5 AP conjugated for detection. NA = not analyzed. 


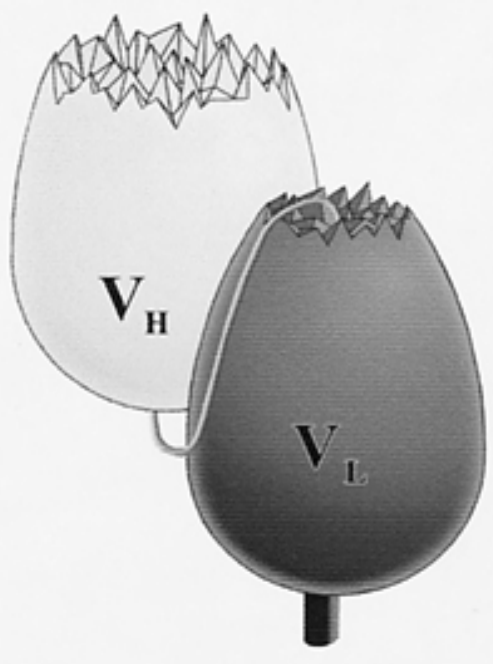

scFv
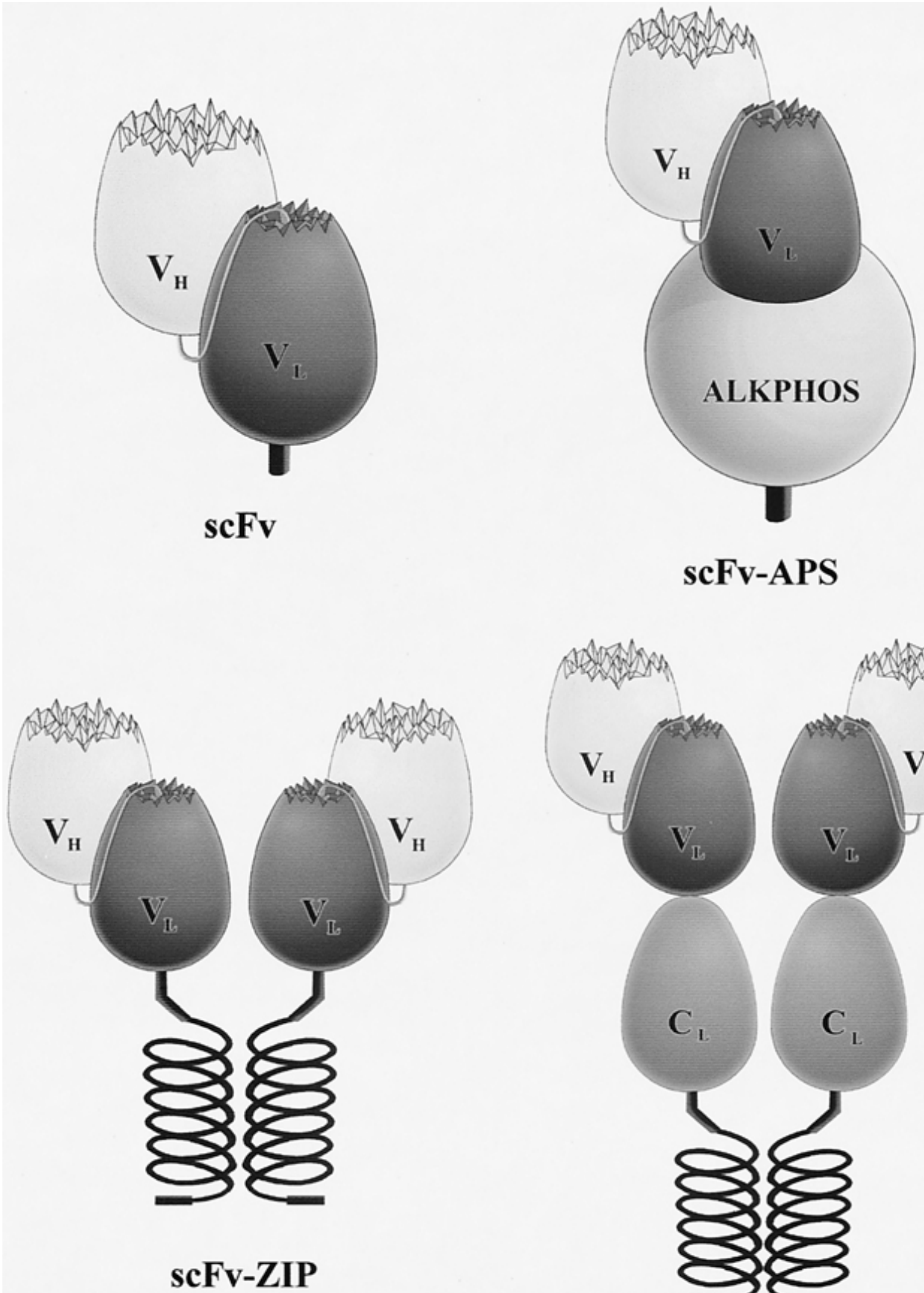

scFv-APS

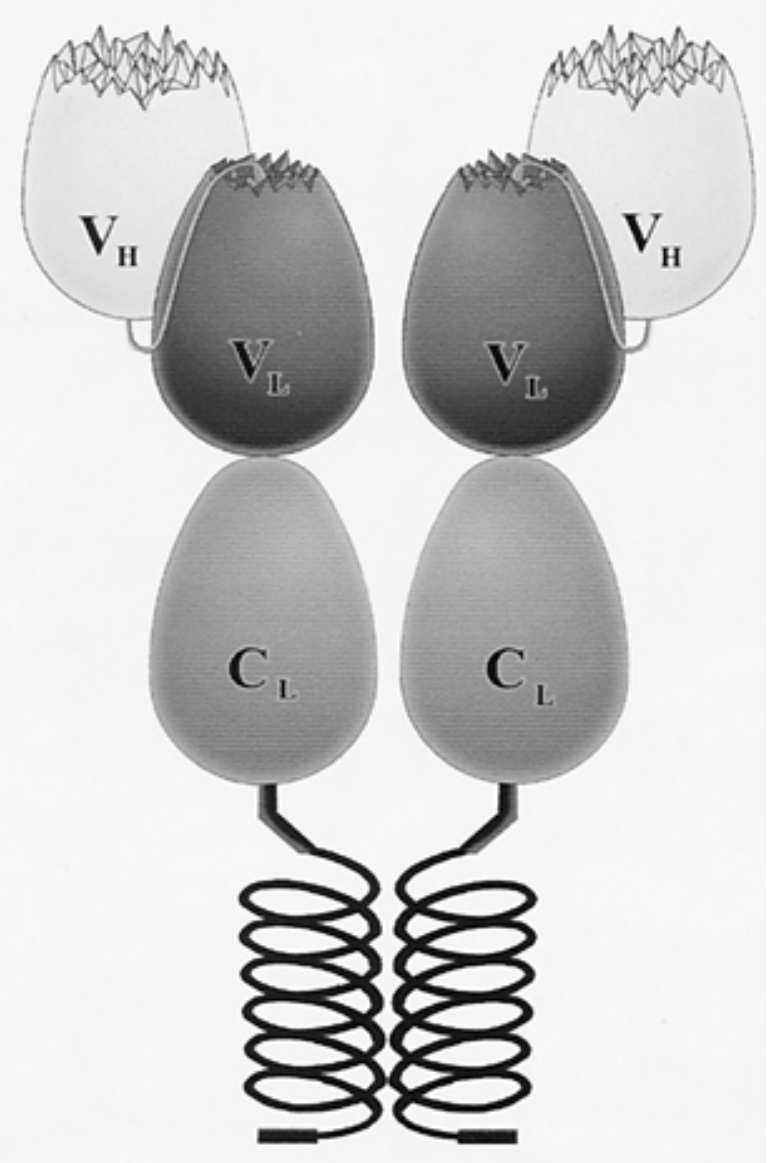

\section{scFv-C $\mathrm{C}_{\mathrm{L}}-\mathrm{ZIP}$}

Fig. 1. Schematic representation of the single-chain variable antibody fragment (scFv) fusion proteins produced. ScFv-APS $=\mathrm{scFv}$ fused to mutated alkaline phosphatase; $\mathrm{ScFv}-\mathrm{ZIP}=\mathrm{scFv}$ fused to the hinge region and $\mathrm{ZIP}$ domain for dimerization; and $\mathrm{ScFv}-\mathrm{C}_{\mathrm{L}} \mathrm{ZIP}=\mathrm{scFv}$ fused with the constant region of a human kappa light chain, the hinge region, and the ZIP domain. 
3CA5scFv-CLZIP was further optimized when the infected plant extracts were prepared with a "complex" extraction buffer. Both $3 \mathrm{DF} 1 \mathrm{scFv}$-ZIP and 3CA5scFv-CLZIP reacted successfully after storage at $-20^{\circ} \mathrm{C}$ in $50 \%$ glycerol for 15 months (Table 2).

Routine CTV detection by recombinant antibody fragments. The AP/S-fused fragments, 3DF1scFv-AP/S and 3CA5scFv-AP/S, were used to detect CTV CP by tissue print direct ELISA, and the results compared with those from a commercial CTV detection kit (Plant Print Diagnòstics SL, Valencia, Spain) using the conventional MCAs 3DF1 and 3CA5. Figure 2 shows the results obtained with some CTV-infected and healthy sweet orange plants. The developed prints show a similar intensity and number of stained areas in the vascular region of sections of sweet orange shoots when using MCA 3DF1 or the recombinant 3DF1scFv-AP/S. The recombinant $3 \mathrm{CA} 5 \mathrm{scFv}-\mathrm{AP} / \mathrm{S}$ was slightly less reactive than the MCA 3CA5. The reaction of a mixture of both scFv-AP/S recomiants was similar to that obtained with the commercially available kit by both CTV-specific MCAs in mixture. In addition, the scFvAP/S had the same specificity as the parental MCAs. The CTV isolate T-397-P was not recognized by 3DF1 immunoglobulin (Ig)G2B or by 3DF1scFv-AP/S, giving only background signal as with the healthy controls. However, this particular CTV strain was detected by 3CA5 (IgG2B) as well as by 3CA5scFv-AP/S.

The results of a comparison of DAS-ELISA tests performed with MCAs or $\mathrm{scFv}$ from the same antibodies are shown in Figure
3. The $\mathrm{OD}_{405 \mathrm{~nm}}$ values obtained with the recombinant ELISA performed with 3DF1scFv-ZIP for coating and 3DF1scFv-APS for detecting were not significantly different to those obtained with conventional DAS-ELISA by 3DF1 conjugated with AP. The recombinant ELISA using both 3CA5-scFv fusion proteins gave lower values than conventional DAS-ELISA using 3CA5 conjugated with AP. However, the $\mathrm{OD}_{405 \mathrm{~nm}}$ values obtained with fully recombinant DAS-ELISA with a mixture of 3DF1scFv-ZIP and 3CA5scFv-CLZIP for coating and 3DF1scFv-AP/S and 3CA5scFv$\mathrm{AP} / \mathrm{S}$ as detecting reagents, were statistically similar to those obtained by DAS-ELISA with a mixture of the 3DF1 and 3CA5 MCAs for coating and the same MCAs conjugated with AP for detection. Figure 3 also illustrates the high trapping efficiency of 3DF1scFv-ZIP, 3CA5scFv-CLZIP, or the mixture of both constructs, compared with those obtained by the corresponding MCAs. No ELISA reaction was obtained with either the 3DF1 MCA or the $3 \mathrm{DF} 1 \mathrm{scFv}$ constructs when they were assayed against CTV isolate T-397-P, maintaining the specificity of the parental 3DF1 MCA for the epitope recognition. The $\mathrm{OD}_{405 \mathrm{~nm}}$ values obtained for this particular CTV isolate did not differ from those given by healthy controls. In addition, the $\mathrm{OD}_{405 \mathrm{~nm}}$ values of the healthy control were similar for all the ELISA combinations assayed indicating a very low background.

To confirm that the fully recombinant ELISA with two specifities (3DF1 and 3CA5) was able to react with a broad spectrum
A

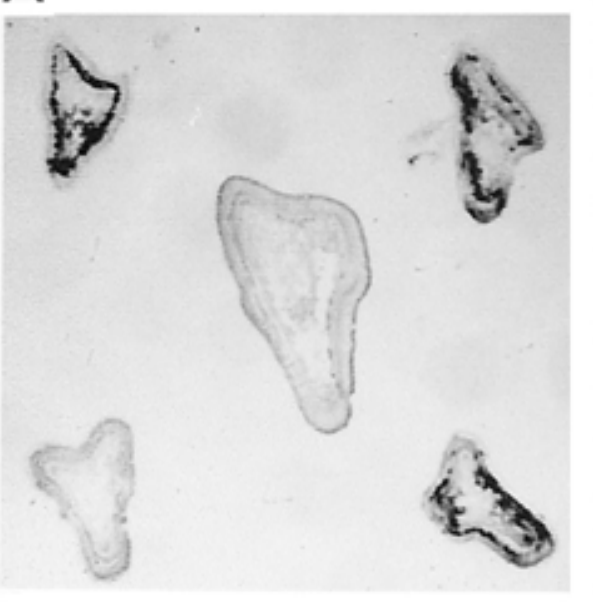

D
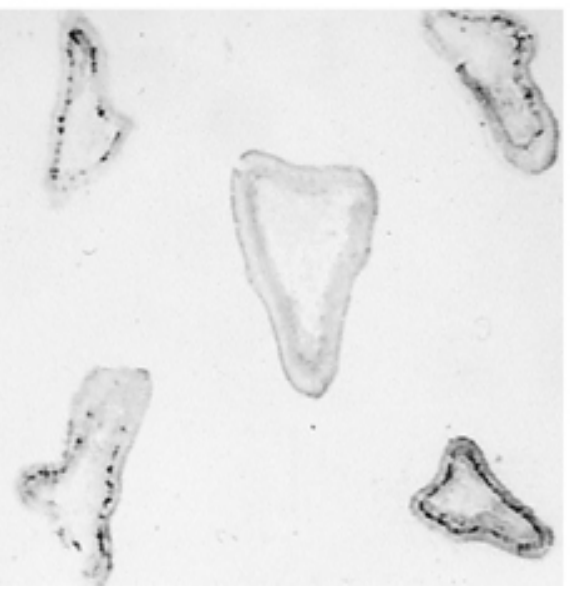

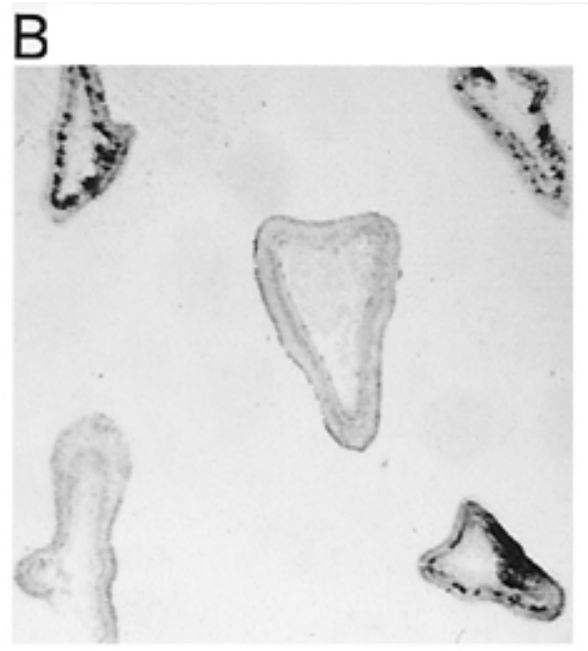

E

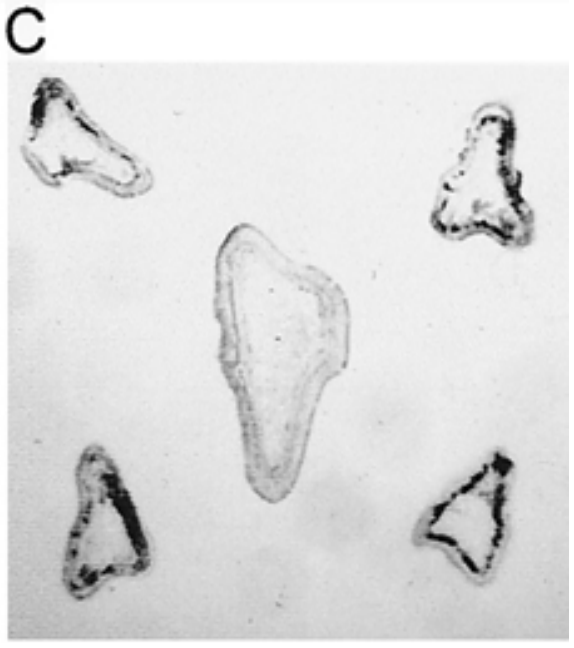

$\mathrm{F}$

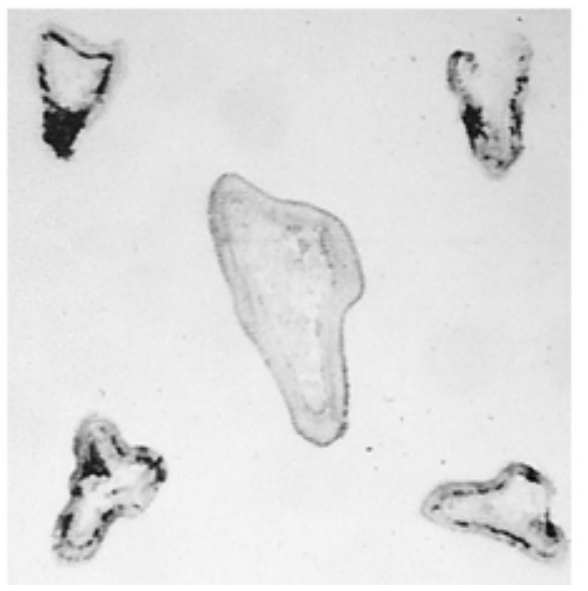

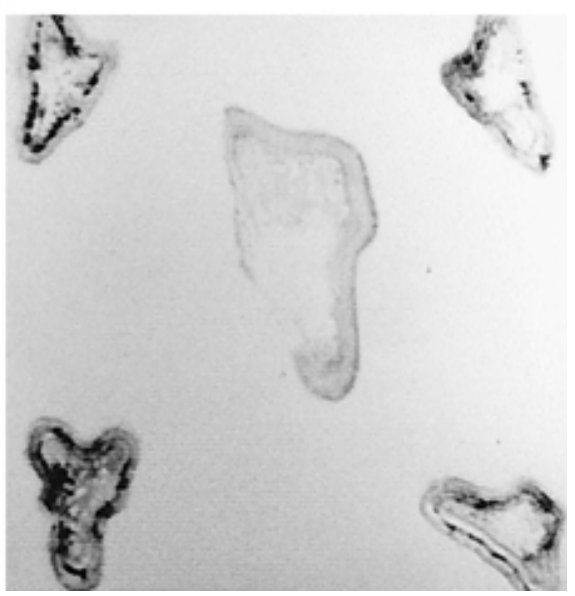

Fig. 2. Tissue print enzyme-linked immunosorbent assay (ELISA) of healthy and Citrus tristeza virus (CTV)-infected sweet orange cv. Pineapple shoots. The Citrus shoots correspond to different CTV isolates: T-388 aggressive (top left), T-300 common (top right), T-397-P common (bottom left), T-302 mild (bottom right), and healthy control (center). Prints were tested by different CTV specific reagents: A, MCA 3DF1 conjugated with AP; B, 3DF1scFv-AP/S; C, MCA 3CA5 AP conjugated; D, 3CA5scFv-AP/S; E, a commercial mixture of AP conjugated MCAs 3DF1 and 3CA5; and F, a mixture of 3DF1scFv-AP/S and $3 \mathrm{CA} 5 \mathrm{scFv}-\mathrm{AP} / \mathrm{S}$. 


\section{$[\because]$ CIID= MCA $/$ MCA-AP \\ $\mathrm{C} / \mathrm{D}=\mathrm{MCA} / \mathrm{MCA}-$ biotin

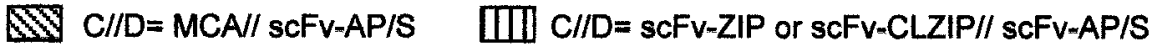

T-388

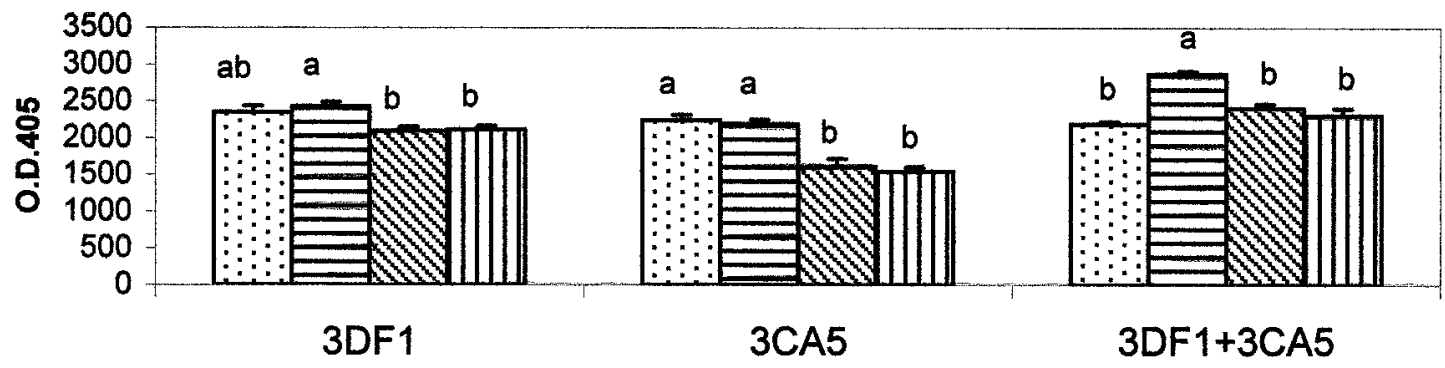

T-397-P

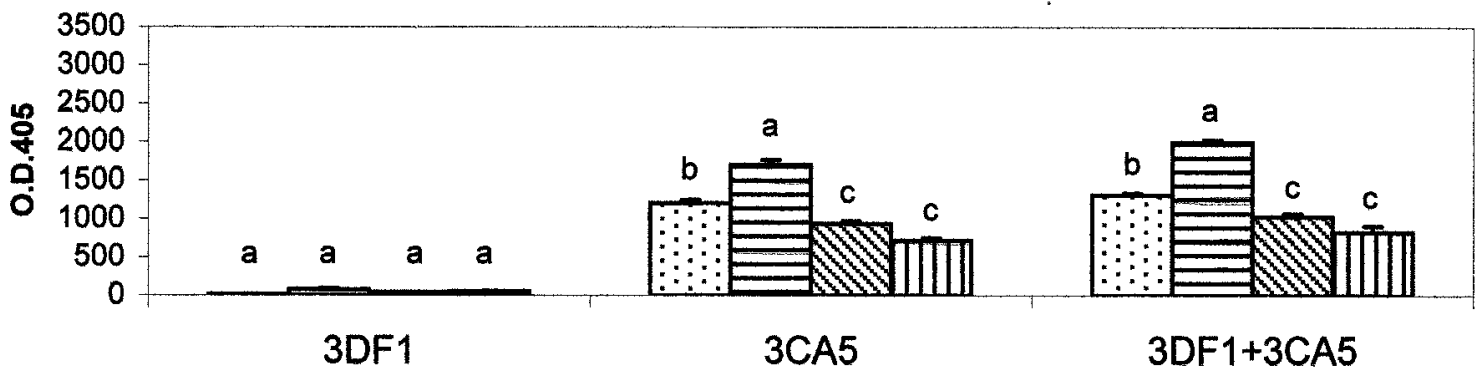

T-302
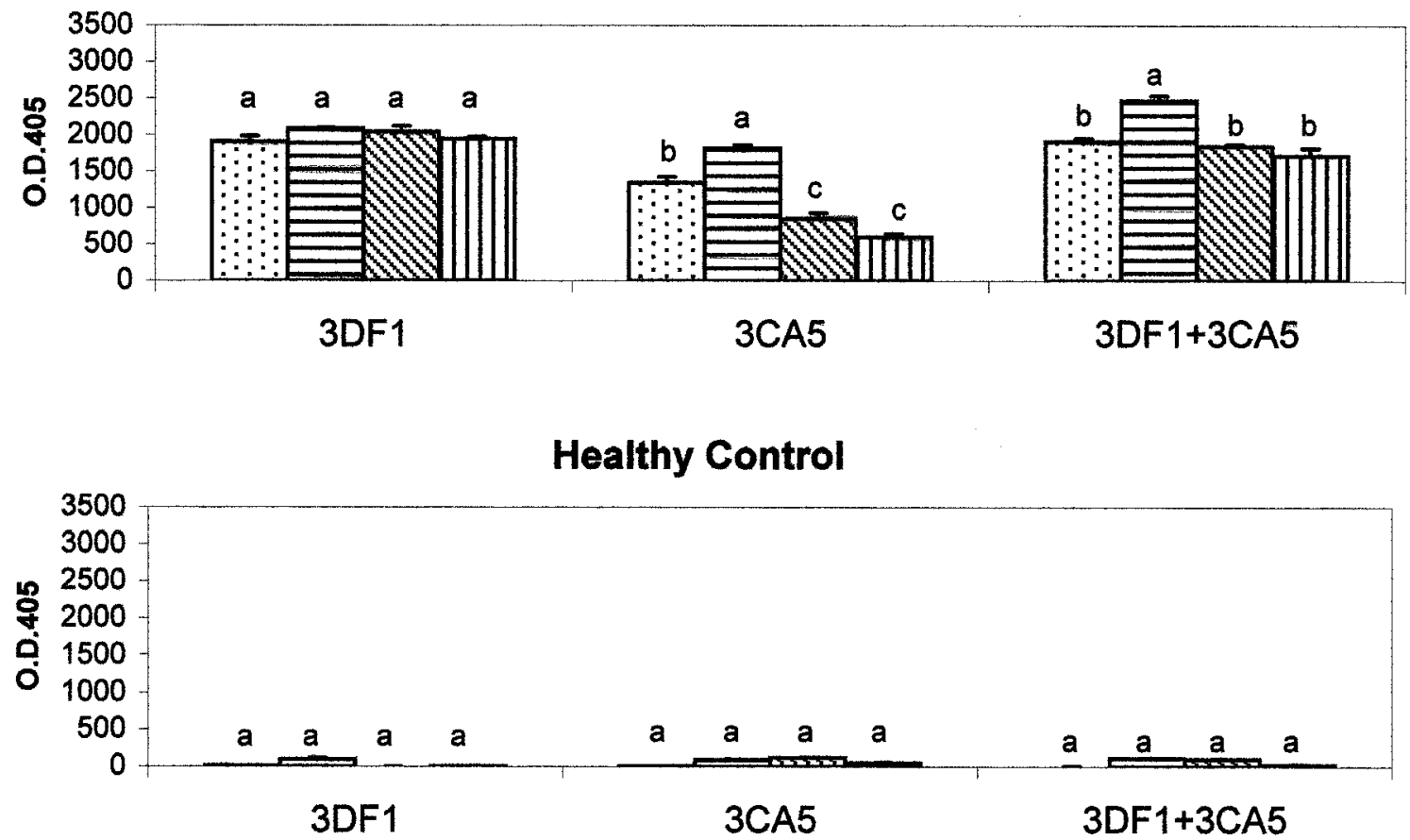

Fig. 3. Comparison of $\mathrm{OD}_{405 \mathrm{~nm}}$ values from three different double-antibody sandwich-enzyme-linked immunosorbent assay (DAS-ELISA) methods: conventional commercially available, semirecombinant, and complete recombinant. The commercial DAS-ELISA was performed by coating microplates with monoclonal antibodies (MCAs) 3DF1, 3CA5, or with a mixture of both, and using alkaline phosphatase or biotin conjugates. The semirecombinant DAS-ELISA was performed by coating microplates with both conventional MCAs alone or in mixture, and using 3DF1scFv-AP/S, 3CA5scFv-AP/S or a mixture of both as detecting antibodies. The fully recombinant DAS-ELISA was performed by coating microplates with 3DF1scFv-ZIP, 3CA5scFv-CLZIP, or with a mixture of both, and with $3 \mathrm{DF} 1 \mathrm{scFv}-\mathrm{AP} / \mathrm{S}, 3 \mathrm{CA} 5 \mathrm{scFv}-\mathrm{AP} / \mathrm{S}$, or a mixture of both as conjugates. These methods were assayed against extracts from healthy sweet orange cv. Pineapple and plants infected with CTV isolates T-388, T-397-P and T-302. Bar codes indicate the reagent used for coating (C) and the reagent used as conjugate (D). Bar and extensions represent the average \pm SE of four replicates. Within the same isolate and the same antibody bars with the same letter are not significantly different at $P=0.05$ according to the LSD test. 
of CTV isolates, 23 characterized CTV isolates from the IVIA collection and CTV-infected and noninfected field samples from different citrus cultivars were tested in a large screening test. The assays were performed by tissue print direct ELISA with a mixture of $3 \mathrm{DF} 1 \mathrm{scFv}-\mathrm{AP} / \mathrm{S}$ and $3 \mathrm{CA} 5 \mathrm{scFv}-\mathrm{AP} / \mathrm{S}$. The results were compared with those obtained from testing the same plant material with the CTV detection kit, which uses a mixture of AP-conjugated MCAs 3DF1 and 3CA5. Samples were also analyzed by DAS-ELISA using a mixture of 3DF1scFv-ZIP and 3CA5scFvCLZIP for coating ELISA microplates and 3DF1scFv-AP/S mixed with $3 \mathrm{CA} 5 \mathrm{scFv}-\mathrm{AP} / \mathrm{S}$ as detecting reagents (fully recombinant ELISA). The results were compared with those obtained by DASELISA with 3DF1 and 3CA5 MCAs for coating and biotin or APconjugated MCAs for detection. The results (healthy or infected) were identical, independent of the kind of immunological assay applied (tissue print or DAS-ELISA) as well as of the kind of reagents used (recombinant or conventional) (data not shown). This screening experiment showed that the recombinant reagents could completely replace the conventional kits.

\section{DISCUSSION}

Production of recombinant antibodies from hybridoma cell lines secreting specific MCAs is well documented. In this work, $\mathrm{scFv}_{\mathrm{V}}$ fusion proteins have been produced and serve as diagnostic reagents specific for CTV with a similar efficiency as their parental MCAs 3DF1 and 3CA5. In plant pathology, scFv fusions have been used for diagnosis of plant viruses $(20,43)$ but their efficiency have never been compared with the parental MCAs. Vector pDAP2/S was used to fuse $3 \mathrm{DF} 1 \mathrm{scF}$ and $3 \mathrm{CA} 5 \mathrm{scFv}$ to a modified $E$. coli-AP with a 35-fold improved specific activity compared with wild-type E. coli-AP. These fusion proteins proved to be efficient recombinant conjugates that were easily produced and facilitate subsequent handling in serological tests. The use of secondary antibodies that can induce nonspecific reactions as well as conventional conjugate preparation by chemical coupling can be avoided. The scFv-AP/S fusions can be used directly in serological tests like tissue print ELISA, a rapid and easily performed technique. The use of 3DF1scFv-AP/S and 3CA5scFv-AP/S in mixture allows large scale testing by tissue print ELISA in a simple and economic way without compromising the sensitivity offered by the parental MCAs. The scFv-AP/S fusion proteins are also excellent substitutes for conjugates in the DAS-ELISA test format.

In order to design a DAS-ELISA based completely on recombinant antibody fragments, bivalent mini-antibodies specific to CTV were constructed, which have the potential to serve as recombinant coating reagents. The mini-antibody $3 \mathrm{DF} 1 \mathrm{scFv}-\mathrm{ZIP}$ is an excellent coating reagent for ELISA plates. In order to achieve the same trapping efficiency in the case of the $3 \mathrm{CA} 5 \mathrm{scFv}$, the respective mini-antibody had to be enlarged by a light chain constant domain. For unknown reasons, the mini-antibody $3 \mathrm{CA} 5 \mathrm{scFv}-\mathrm{ZIP}$ was partially inhibited by the plant extract when used as coating reagent. Similar inhibition problems have been described (43). Nevertheless, in our work inhibition could be avoided when the 3CA5-CLZIP is used for trapping the antigen. The four constructs, 3DF1scFv-AP/S, 3CA5scFv-AP/S, 3DF1scFv-ZIP, and 3CA5scFvCLZIP, allow the performance of a fully recombinant DASELISA for the detection of CTV-isolates, without the need of monoclonal or polyclonal antibodies.

Statistical analysis of the data represented in Figure 3 showed that the ability of 3DF1 MCAs or their recombinant constructs to react against CTV isolates using different ELISA formats was similar. In contrast, the efficiency of the ELISAs performed with $3 \mathrm{CA} 5 \mathrm{scFv}$ fusions was slightly lower than that achieved with conventional 3CA5 ELISAs. When both 3DF1scFv and 3CA5scFv fusion proteins were used in mixture it was as sensitive as the conventional AP DAS-ELISA using both MCAs. However, the highest OD values were obtained by conventional biotin/streptavidin ELISA, due to the amplification effect of this system.

In contrast with data previously reported (43), the $\mathrm{scFv}$ fusion proteins produced against CTV were very stable and retained activity during storage for long periods, increasing their practical value for diagnosis.

Both serological techniques, tissue print ELISA, and DASELISA, performed with recombinant antibodies were successfully tested for routine detection of CTV in different laboratories, by previously characterized isolates as well as field-infected trees. The excellent performance of the recombinant CTV-specific antibodies obtained may obviate the need for conventional MCA production from hybridoma cells. The ability of the scFvs in their binding against all the CTV isolates tested suggests that these particular constructs may be effective in inducing resistance in transgenic citrus plants.

\section{ACKNOWLEDGMENTS}

This work was supported by grants AIR3-CT94-1046 (EU), SC94-085, and SC98-060 (INIA, Spain), and partially supported by CNR-RAISA grant 94.00360.PF38 and CNR-Biotechnologie grant 95.01749.CT14 (Italy). We thank C. Cantale and S. Guida (ENEA), S. Hirschl (IAM), A. Sanz (INGENASA), and E. Camarasa, M. T. Gorris, and L. Navarro (IVIA) for scientific and technical collaboration; E. Carbonell and V. Real (IVIA) for statistical analysis; and L. G. Pereira (IBMP, Porto, Portugal) and C. Varveri (Benaki Institute, Athens) for the additional testing of the produced recombinant antibodies. The mRNA from hybridoma was supplied by INGENASA, Madrid.

\section{LITERATURE CITED}

1. Ballester-Olmos, J. F., Pina, J. A., Carbonell, E., Moreno, P., Hermoso de Mendoza, A., Cambra, M., and Navarro, L. 1993. Biological diversity of citrus tristeza virus (CTV) isolates in Spain. Plant Pathol. 42:219-229.

2. Bar-Joseph, M., Garnsey, S. M., Gonsalves, D., Moscovitz, M., Purcifull, D. E., Clark, M. F., and Loebenstein, G. 1979. The use of enzyme-linked immunosorbent assay for detection of citrus tristeza virus. Phytopathology 69:190-194.

3. Bar-Joseph, M., and Lee, R. 1989. Citrus tristeza virus. No. 353 in: AAB Descriptions of Plant Viruses. Commonw. Mycol. Inst./Assoc. Appl. Biol, Warwick, U.K.

4. Bar-Joseph, M., Marcus, R., and Lee, R. F. 1989. The continuous challenge of citrus tristeza virus control. Annu. Rev. Phytopathol. 27: 291-316.

5. Bird, R. E., Hardman, K. D., Jacobson, J. W., Johnson, S., Kaufman, B. M., Lee, S., Lee, T., Pope, S. H., Riordan, G. S., and Whitlow, M. 1988. Single-chain antigen-binding proteins. Science 242:423-426.

6. Boonham, N., and Baker, I. 1998. Strain specific recombinant antibodies to potato virus Y potyvirus. J. Virol. Methods 74:193-199.

7. Cambra, M. 1994. El virus de la tristeza de los cítricos. Nueva situación en la Comunidad Valenciana. Phytoma 58:26-31.

8. Cambra, M., Ballester-Olmos, J. F., Pina, J. A., Laviña, A., and Camarasa, E. 1989. Distinction of populations infected with severe and common strains of citrus tristeza virus in Spain, by DAS-ELISAc (quantitative). Fruits 44:335-341.

9. Cambra, M., Camarasa, E., Gorris, M. T., Garnsey, S. M., Gumpf, D. J., and Tsai, M. C. 1993. Epitope diversity of citrus tristeza virus (CTV) isolates in Spain. Pages 33-38 in: Proc. Conf. Int. Organ. Citrus Virol., 12th. P. Moreno, J. V. Da Graça, and L. W. Timmer, eds. IOCV, Riverside, CA.

10. Cambra, M., Garnsey, S. M., Permar, T. A., Henderson, C. T., Gumpf, D. J., and Vela, C. 1990. Detection of citrus tristeza virus (CTV) with a mixture of monoclonal antibodies. (Abstr.) Phytopathology 80(suppl.):S1034.

11. Cambra, M., Gorris, M. T., Camarasa, E., Román, M. P., Narváez, G., Terrada, E., Martínez, M. C., and Torres, M. A. 1999. ImmunoimpresiónELISA: Método ideal para detección del virus de la tristeza de los cítricos. Comun. Valenciana Agrar. 13:4-14.

12. Cambra, M., Gorris, M. T., Marroquín, C., Román, M. P., Olmos, A., Martinez, M.C., Hermoso de Mendoza, A., López, A., and Navarro, L. 2000. Incidence and epidemiology of Citrus tristeza virus in the Valencian community of Spain. Virus Res. (In press.)

13. Cambra, M., Moreno, P., and Navarro, L. 1979. Detección rápida del virus de la tristeza de los cítricos (CTV) mediante la técnica inmunoenzimática ELISA-sandwich. An. Inst. Nac. Invest. Agrar. Ser. Prot. Veg. 
12:115-121.

14. Clackson, T., Hoogenboom, H. R., Griffiths, A., and Winter, G. 1991. Making antibody fragments using phage display libraries. Nature 352:624-628.

15. Duncancel, F., Gillet, D., Carrier, A., Lajeunesse, E., Ménez, A., and Boulain, J. 1993. Recombinant colorimetric antibodies: Construction and characterization of a bifunctional $\mathrm{F}(\mathrm{ab}) 2 /$ alkaline phosphatase conjugate produced in Escherichia coli. Bio/Technology 11:601-605.

16. Engelhardt, O., Grabherr, R., Himmler, G., and Rüker, F. 1994. Two-step cloning of antibody variable domains in a phage display vector. Biotechniques 17:44-46.

17. Garnsey, S. M., and Cambra, M. 1991. Enzyme-linked immunosorbent assay (ELISA) for citrus pathogens. Pages 193-216 in: Graft-Transmissible Diseases of Citrus: Handbook for Detection and Diagnosis. C. N. Roistacher, ed. IOCV-FAO, Rome.

18. Garnsey, S. M., Permar, T. A., Cambra, M., and Henderson, C. T. 1993. Direct tissue blot immunoassay (DTBIA) for detection of citrus tristeza virus (CTV). Pages 39-50 in: Proc. Conf. Int. Organ. Citrus Virol., 12th. P. Moreno, J. V. Da Graça, and L. W. Timmer, eds. IOCV, Riverside, CA.

19. Ge, L., Knappik, A., Pack, P., Freund, C., and Plückthun, A. 1995. Expressing antibodies in Escherichia coli. Pages 229-266 in: Antibody Engineering. 2nd ed. C. A. K. Borrabaeck, ed. Oxford University Press, London.

20. Griep, R. A., Prins, M., van Twisk, C., Keller, H. J. H. G., Kerschbaumer, R. J., Kormelink, R., Goldbach, R. W., and Schots, A. 2000. Application of phage display in selecting Tomato spotted wilt virus-specific single-chain antibodies (scFvs) for sensitive diagnosis in ELISA. Phytopathology 90:183-190.

21. Harper, K., Kerschbaumer, R. J., Ziegler, A., Macintosh, S. M., Cowan, G. H., Himmler, G., Mayo, M. A., and Torrance, L. 1997. A scFv-alkaline phosphatase fusion protein which detects potato leafroll luteovirus in plant extracts by ELISA. J. Virol. Methods 63:237-242.

22. Hoogenboom, H. R., Griffiths, A. D., Johnson, K. S., Chiswell, D. J., Hudson, P., and Winter, G. 1991. Multi-subunit proteins on the surface of filamentous phage: Methodologies for displaying antibody (Fab) heavy and light chains. Nucleic Acids Res. 19:4133-4137.

23. Huston, J. S., Levinson, D., Mudgett-Hunter, M., Tai, M., Novontny, J., Margolies, M. N., Ridge, R. J., Bruccoleri, R. E., Harber, E., Crea, R., and Oppermann, H. 1988. Protein engineering of antibody binding sites: Recovery of specific activity in an anti-digoxin single-chain Fv analogue produced in Escherichia coli. Proc. Natl. Acad. Sci. USA 85:5879-5883.

24. Kabat, E. A., Wu, T. T., Reid-Miller, M., Perry, H. M., and Gottesman, K. S. 1987. Sequences of proteins of immunological interest. 4th ed., U.S. Dep. Health Hum. Serv., U.S. Gov. Printing Office.

25. Karasev, A. V., Boyko, V. P., Gowda, S., Nikolaeva, O. V., Hilf, M. E., Koonin, E. V., Niblett, C. L., Cline, K., Gumpf, D. J., Lee, R. F., Garnsey, S. M., and Dawson, W. O. 1995. Complete sequence of the citrus tristeza virus RNA genome. Virology 208:511-520.

26. Kerschbaumer, R. J., and Himmler, G., 1999. Dedicated expression vectors for the production of diagnostic reagents. Pages 57-81 in: Recombinant Antibodies-Application in Plant Science and Plant Pathology. K. Harper and A. Ziegler, eds. Taylor \& Francis, London.

27. Kerschbaumer, R. J., Hirschl, S., Kaufmann, A., Ibl, M., Koenig, R., and Himmler, G. 1997. Single-chain Fv fusion proteins suitable for coating and detecting reagents in a double antibody sandwich enzyme-linked immunosorbent assay. Anal. Biochem. 249:219-227.

28. Kerschbaumer, R. J., Hirschl, S., Schwager, C., Ibl, M., and Himmler, G. 1996. pDAP2: A vector for construction of alkaline phosphatase fusionproteins. Immunotechnology 2:145-150.

29. Köhler, G., and Milstein, C. 1975. Continuous cultures of fused cells secreting antibodies of predefined specificity. Nature (London) 257: 495-497.

30. Lin, N. S., Hsu, H. Y., and Su, H. T. 1990. Immunological detection of plant viruses and mycoplasmalike organism by direct tissue blotting on nitrocellulose membranes. Phytopathology 80:824-828.

31. Mandecki, W., Shallcross, M. A., Sowadski, J., and Tomazic-Allen, S. 1991. Mutagenesis of conserved residues within the active site of Es- cherichia coli alkaline phosphatase yields enzymes with increased $\mathrm{k}_{\mathrm{cat}}$. Protein Eng. 4:801-804.

32. Manjunath, K. L., Hooker, M., Pappu, H. R., Pappu, S. S., Powell, C. A., Bar-Joseph, M., Niblett, C. L., Garnsey, S. M., and Lee, R. F. 1996. Synthesis of a functional single-chain antibody against citrus tristeza closterovirus in bacteria. Pages 38-46 in: Proc. Conf. Int. Organ. Citrus Virol., 13th. J. V. Da Graça, P. Moreno, and R. K. Yokomi, eds. IOCV, Riverside, CA.

33. Nikolaeva, O. V., Karasev, A. V., Powell, C. A., Garnsey, S. M., and Lee, R. F. 1997. Modulation of the antigenic reactivity of the citrus tristeza virus coat protein. J. Virol. Methods 206:97-105.

34. Pack, P., and Plückthun, A. 1992. Miniantibodies: Use of amphipathic helices to produce functional flexible linked dimeric Fv fragments with high avidity in Escherichia coli. Biochemistry 31:1579-1584.

35. Pappu, H. R., Pappu, S. S., Kano, T., Koizumi, M., Cambra, M., Moreno, P., Su, H. J., Garnsey, S. M., Lee, R. F., and Niblett, C. L. 1995. Mutagenic analysis and localization of a highly conserved epitope near the amino terminal end of the citrus tristeza closterovirus capsid protein. Phytopathology 85:1311-1315.

36. Plückthun, A. 1991. Antibody engineering: Advances from the use of Escherichia coli expression systems. BioTechnol. Adv. 9:545-551.

37. Plückthun, A., Krebber, A., Krebber, C., Horn, U., Knüpfer, U., Wenderoth, R., Nieba, L., Proba, K., and Riesenberg, D. 1996. Producing antibodies in Escherichia coli: From PCR to fermentation. Pages 203-252 in: Antibody Engineering: A Practical Approach. J. M. McCafferty, H. R. Hoogenboom, and D. J. Chiswell, eds. IRL Press, Oxford, WA.

38. Plückthun, A., and Skerra, A. 1989. Expression of functional antibody Fv and Fab fragments in Escherichia coli. Methods Enzymol. 178:497-515.

39. Roistacher, C. N., and Bar-Joseph, M. 1984. Transmission of tristeza and sedling yellows tristeza virus by Aphis gossypii from sweet orange, grapefruit, and lemon to mexican lime, grapefruit, and lemon. Pages 918 in: Proc. Conf. Int. Organ. Citrus Virol., 9th. S. M. Garnsey and L. W. Timmer, eds. IOCV, Riverside, CA.

40. Roistacher, C. N., and Moreno, P. 1991. The worldwide threat from destructive isolates of citrus tristeza virus: A review. Pages 1-19 in: Proc. Conf. Int. Organ. Citrus Virol., 11th. R. H. Brlansky, R. F. Lee, and L. W. Timmer, eds. IOCV, Riverside, CA.

41. Sambrook, J., Fritsch, E. F., and Maniatis, T. 1989. Molecular Cloning: A Laboratory Manual. Cold Spring Harbor Laboratory, Cold Spring Harbor, NY.

42. Susi, P., Ziegler, A., and Torrance, L. 1998. Selection of single-chain variable fragment antibodies to black currant reversion associated virus from a synthetic phage display library. Phytopathology 88:230-233.

43. Toth, R. L., Harper, K., Mayo, M. A., and Torrance, L. 1999. Fusion proteins of single-chain variable fragments derived from phage display libraries are effective reagents for routine diagnosis of potato leafroll virus infection in potato. Phytopathology 89:1015-1021.

44. Vela, C., Cambra, M., Cortés, E., Moreno, P., Miguet, J. G., Pérez de San Román, C., and Sanz, A. 1986. Production and characterization of monoclonal antibodies specific for citrus tristeza virus and their use for diagnosis. J. Gen. Virol. 67:91-96.

45. Vela, C., Cambra, M., Sanz, A., and Moreno, P. 1988. Use of specific monoclonal antibodies for diagnosis of citrus tristeza virus. Pages 56-61 in: Proc. Conf. Int. Organ. Citrus Virol., 7th. L. W. Timmer, S. M. Garnsey, and L. Navarro, eds. IOCV, Riverside, CA.

46. Vives, M. C., Rubio, L., López, C., Navas-Castillo, J., Albiach-Martí, M. R., Dawson, W. O., Guerri, J., Flores, R., and Moreno, P. 1999. The complete genome sequence of a mild citrus tristeza virus isolate: Uneven distribution of the nucleotide differences in comparison with a severe virus isolate. J. Gen. Virol. 80:811-816.

47. Winter, G., Griffiths, A. D., Hawkins, R. E., and Hoogenboom, H. R. 1994. Making antibodies by phage display technology. Ann. Rev. Immunol. 12:433-455.

48. Ziegler, A., Torrance, L., Macintosh, S. M., Cowan, G. H., and Mayo, M. A. 1995. Cucumber mosaic cucumovirus antibodies from a synthetic phage display library. Virology 214:235-238. 